ISSN: 1858-4837; E-ISSN: 2598-019X

Volume 16, Nomor 1 (2021),

https://jurnal.uns.ac.id/region

DOI: 10.20961/region.v16i1.44149

\title{
Kriteria ketahanan kota berdasarkan jenis bencana prioritas di Kota Balikpapan
}

\section{Criteria of resilient city based on disaster type in Balikpapan City}

\author{
Ariyaningsih $^{1}$, B Erik ${ }^{1}$, R B Sukmara ${ }^{2}$ \\ ${ }^{1}$ Program Studi Perencanaan Wilayah dan Kota, Institut Teknologi Kalimantan \\ 2 Program Studi Teknik Sipil, Institut Teknologi Kalimantan
}

Corresponding author's email: ariyaningsih@lecturer.itk.ac.id

\begin{abstract}
Abstrak. Resilient City merupakan konsep yang memiliki hubungan dengan pembangunan berkelanjutan, yang juga dibangun di atas tiga dimensi mitigasi, adaptasi, dan respons. Konsep tersebut sangat berkaitan dengan bahaya yang akan dihadapi oleh sebuah kota. Bahaya tersebut dapat mengancam kehidupan manusia, dan mengakibatkan kerusakan dan kerugian. Salah satu bentuk bahaya adalah bencana, dimana di Indonesia merupakan salah satu negara dengan frekuensi bencana paling tinggi di dunia. Salah satu Kota dengan resiko cukup tinggi terhadap bencana adalah Kota Balikpapan, dengan kejadian bencana di Kota Balikpapan yaitu bencana banjir dan tanah longsor, abrasi, puting beliung, dan kebakaran hutan. Kota Balikpapan merupakan daerah strategis untuk pembangunan di Provinsi Kalimantan Timur, sehingga diperlukan sebuah konsep perencanaan kota yang dapat memiliki ketahanan terhadap bencana yang akan dihadapi. Adanya upaya untuk menurunkan risiko terhadap bencana, dengan menggunakan konsep resilient city. Metode penelitian ini menggunakan metode analisis AHP (Analytical Hierarchy Process) yang digunakan untuk menganalisis jenis bencana prioritas yang akan mempengaruhi ketahanan Kota Balikpapan. Hasil yang diperoleh adalah bencana banjir menjadi prioritas yang mempengaruhi ketahanan Kota Balikpapan. Metode kedua adalah dengan analisis Delphi yang digunakan untuk menganalisis kriteria ketahanan Kota yang di butuhkan agar Kota Balikpapan dapat menjadi tangguh terhadap bencana banjir tersebut. Hasil yang didapat adalah kriteria aspek kesehatan, aspek infrastruktur, aspek strategi, dan aspek sosial budaya masyarakat
\end{abstract}

Kata Kunci: AHP; Bencana; Delphi; Kota Berketahanan

Received : September 1, 2020; Accepted: December 1, 2020; Available online: January 30, 2021

Copy right @ 2021, REGION: Jurnal Pembangunan Wilay ah dan Perencanaan Partisipatif 


\begin{abstract}
Resilient City is a concept that has a relationship with sustainable development, which is also built on three dimensions of mitigation, adaptation, and response. This concept is closely related to the hazards that will be faced by a city. These hazards can threaten human life and result in damage and loss. One form of hazard is a disaster, in which Indonesia is one of the countries with the highest frequency of disasters in the world. One of the cities with a fairly high risk of disaster is the City of Balikpapan, with disasters such as floods and landslides, abrasions, tornadoes, and forest fires. Balikpapan City is a strategic area for development in East Kalimantan Province, so we need a city planning concept that can be resilient to the disasters it will face. There are efforts to reduce the risk of disasters, using the concept of a resilient city. This research method uses the AHP (Analytical Hierarchy Process) analysis method which is used to analyze the types of priority disa sters that will affect the resilience of Balikpapan City. The results obtained are flood disasters which become a priority disaster that affects the resilience of Balikpapan City. The second method is Delphi analysis which is used to analyze the criteria for city resilience needed so that the City of Balikpapan can be resilient to flood disasters. The results obtained are criteria for health aspects, infrastructure aspects, strategic aspects, and socio-cultural aspects of society.
\end{abstract}

Keywords: AHP; Delphi; Disaster; Resilient City

\title{
1. Pendahuluan
}

Berdasarkan penilaian indeks resiko bencana, Provinsi Kalimantan Timur merupakan provinsi dengan resiko bencana cukup tinggi dengan nilai 173,4 [1]. Dari tahun 2009 hingga 2018 jumlah total kejadian bencana di Kalimantan Timur yaitu 207 kejadian dan 101 kejadian bencana tanah longsor, 5 kejadian abrasi, 52 kejadian puting beliung, 7 kejadian kekeringan, 187 kejadian kebakaran hutan, dan 1 kejadian gempa bumi, jumlah total terbanyak adalah kejadian bencana banjir dan kebakaran hutan [1]. Dari penilaian indeks resiko bencana tersebut, Kota Balikpapan merupakan lokasi prioritas pertama untuk penurunan indeks resiko bencana dengan nilai indeks resiko adalah 159,2 dengan semakin tingginya nilai resiko bencana maka daerah tersebut memiliki tingkat resiko terpapar bencana semakin tinggi [2].

Terdapat bencana banjir dan tanah longsor, abrasi, puting beliung, dan kebakaran hutan dengan jumlah kejadian yaitu 48 kejadian bencana banjir, 42 kejadian bencana longsor, 3 kejadian abrasi, 14 kejadian puting beliung, dan 3 kejadian kebakaran hutan periode 2009 hingga 2018 [3]. Dari kejadian bencana tersebut dapat menimbulkan dampak seperti adanya kerusakan baik secara langsung, maupun tidak langsung yang dapat mempengaruhi sosial dan ekonomi perkotaan [4]. Berdasarkan BPBD Kota Balikpapan [3], jumlah rumah rusak berat sebanyak 399 rumah dan mengakibatkan korban meninggal sebanyak 55 orang. Untuk itu diperlukan rencana pembangunan dan pengembangan kota yang memiliki ketahanan terhadap bencana, kota yang memiliki ketahanan terhadap bencana, kota berketahanan (resilient city) adalah kota yang siap menghadapi serangan dari semua jenis ancaman yang mengancam dan menanggulangi kerugian-kerugian yang ditimbulkan oleh bencana [5]. Kota berketahanan juga memiliki kemampuan untuk cepat kembali ke kondisi semula sebelum terjadinya bencana. 
Kota berketahanan (resilient city) adalah salah satu upaya mengembangkan kapasitas untuk membantu menyerap guncangan di masa depan dan menekankan pada sistem dan infrastruktur sosial, ekonomi, dan teknisnya sehingga tetap dapat mempertahankan fungsi, struktur, sistem, dan identitas yang pada dasarnya sama. Konsep ketahanan kota memiliki arti sebagai bentuk kapasitas individu, masyarakat, dan system dari sebuah kota unt uk bisa bertahan, beradaptasi, serta mengurangi dampak, dan dapat tumbuh terhadap tekanan (stress) yang terus menerus serta guncangan (shock) besar yang dihadapi. Dan sebagai proses membangun ketahanan kota, perlu untuk melihat, menelaah, dan mempelajari kota secara menyeluruh dengan cara memahami sistem yang bekerja dan membentuk kota tersebut, hubungan keterkaitan yang dimiliki sistem tersebut, serta risiko yang mungkin dihadapinya. Dengan memperkuat sistem-sistem tersebut serta memahami potensi tekanan (stress) dan guncangan (shock) yang akan dihadapi, sebuah kota akan mampu menyusun rencana pengembangan ke arah yang lebih baik [6]. Konsep kota berketahanan didasarkan pada antisipasi, mitigasi dan pengurangan dampak fisik, ekonomi dan sosial terhadap bencana dalam kota [7].

Kota berketahanan juga erat kaitannya dengan adaptasi, mitigasi, dan respons. Adaptasi dapat digambarkan sebagai kemampuan atau kapasitas dari sebuah sistem yang dapat dirubah karakteristik maupun perilakunya sehingga dapat menyesuaikan keadaan eksisiting atau mengantisi pasi faktor eksternal. Dapat disimpulkan bahwa adaptasi adalah suatu sistem kota yang mampu menyesuaikan keadaan terhadap ancaman yang dihadapai [7]. Sedangkan mitigasi dalah serangkaian upaya untuk mengurangi risiko bencana, baik melalui pembangunan fisik maupun penyadaran dan peningkatan kemampuan menghadapi ancaman bencana [2] dan respons merupakan bagian dari ketahanan kota sebgai bentuk kemampuan kota untuk memeberikan tanggapan berdasarkan ancaman yang dihadapi.

Penelitian ini dilakukan untuk melihat bagaimana penerapan konsep resilient city diterapkan di Kota Balikpapan. Sehingga dengan adanya konsep resilient city di Kota Balikpapan diharapkan dapat menjadi saran bagi Pemerintah Kota Balikpapan agar dapat menyusun kajian lebih lanjut dalam pembuatan dokumen perencanaan ketahanan kota, yang dapat digunakan sebagai acuan penurunan indeks resiko bencana Provinsi Kalimantan Timur. Sedangkan tujuan dari penelitian ini adalah menganalisa kriteria ketahanan kota (resilient city) berdasarkan jenis bencana prioritas di Kota Balikpapan.

\section{Metode}

\subsection{Sintesa teori}

Variabel penelitian yang berasal dari sintesa tinjauan pustaka dapat dilihat pada Tabel 1.

Tabel 1. Sintesa tinjauan pustaka.

\begin{tabular}{lll}
\hline Aspek & Indikator & Variabel \\
\hline Bencana & Bahaya & Mengganggu \\
& Mengancam \\
& Kerusakan \\
& Kerugian \\
\hline
\end{tabular}




\begin{tabular}{lll}
\hline Aspek & Indikator & Variabel \\
\hline Ketahanan Kota & Resilient City & Adaptasi \\
& & Respons \\
Kriteria Ketahanan Kota & Kesehatan & Layanan Kesehatan \\
& Ekonomi & Pendapatan daerah \\
& Infrastruktur & Air \\
& Energi \\
& Konfigurasi spasial dan konektivitas jalan \\
& Transportasi \\
& Perlindunganstruktur \\
& Infrastruktur hijau \\
& Desain dan bangunan \\
& Teknologi daninformasi \\
& Ketersediaan asset alam dan buatan \\
\hline
\end{tabular}

\subsection{Teknik analisis}

Penelitian ini merupakan penelitian campuran, yaitu suatu langkah penelitian dengan menggabungkan dua bentuk pendekatan dalam penelitian, yaitu kualitatif dan kuantitatif. Berdasarkan keseluruhan tinjauan pustaka didapat beberapa variabel yang digunakan untuk menganalisa kriteria penerapan konsep kota berketahanan yang sesuai berdasarkan jenis bencana di Kota Balikpapan, pada Tabel 2 dijelaskan variabel-variabel yang dipilih berdasarkan kesesuaian terhadap objek penelitian.

Tabel 2. Variabel penelitian.

\begin{tabular}{|c|c|c|c|}
\hline Sasaran & Indikator & Analisa & Variabel \\
\hline $\begin{array}{l}\text { Mengi dentifikasi jenis bencana } \\
\text { prioritas yang mempengaruhi } \\
\text { keta ha nan Kota Balikpapan }\end{array}$ & Bahaya & $\mathrm{AHP}$ & $\begin{array}{l}\text { Mengganggu } \\
\text { Mengancam } \\
\text { Kerusakan } \\
\text { Kerugian }\end{array}$ \\
\hline $\begin{array}{l}\text { Menga nalisa kriteria keta hanan } \\
\text { kota (resilient city) berdasarkan } \\
\text { jenis bencana di Kota }\end{array}$ & $\begin{array}{l}\text { Kesehatan } \\
\text { Ekonomi } \\
\text { Infrastruktur }\end{array}$ & Del phi & $\begin{array}{l}\text { Layanan Kesehatan } \\
\text { Pendapatan Da erah } \\
\text { Air }\end{array}$ \\
\hline Balikpapan & & & $\begin{array}{l}\text { Energi } \\
\text { Konektivitas jalan } \\
\text { Trans portasi } \\
\text { Perlindungan struktur } \\
\text { Infrastruktur hijau } \\
\text { Desiandan bangunan } \\
\text { Teknologi dan informasi } \\
\text { Ketersediaan asset alam dan buatan }\end{array}$ \\
\hline
\end{tabular}

\section{Hasil dan pembahasan}

\subsection{Analisa bencana prioritas}

Penentuan jenis bencana prioritas menggunakan metode Analytical Hierarchy Process (AHP) dengan software super decisions. Hasil dari analisis ini adalah bobot bencana prioritas dari masing-masing jenis bencana berdasarkan variabel yang telah ditentukan yaitu variabel mengganggu, mengancam, kerusakan, dan kerugian. Jenis-jenis bencana adalah bencana banjir, tanah longsor, puting beliung, abrasi, dan kebakaran hutan. Terdapat tiga langkah 
dalam AHP yaitu: menyusun hirarki (Gambar 1), matriks perbandingan, dan kesimpulan bobot.

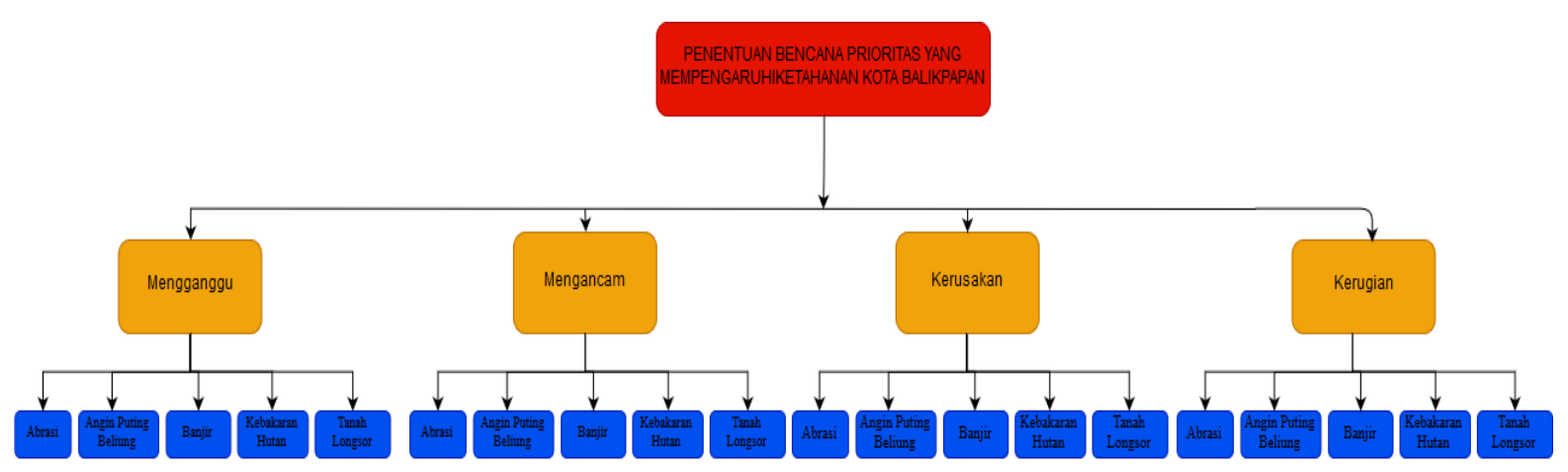

Gambar 1. Hirarki AHP.

Tabel 3. Matriks perbandingan nilai bobot kriteria.

\begin{tabular}{lcccc}
\hline & Mengganggu & Mengancam & Kerusakan & Kerugian \\
\hline Mengganggu & 1.00 & 3.21 & 1.48 & 1.69 \\
Mengancam & 0.31 & 1.00 & 1.38 & 0.72 \\
Kerusakan & 0.68 & 0.65 & 1.00 & 1.93 \\
Kerugian & 0.59 & 0.89 & 0.52 & 1.00 \\
\hline
\end{tabular}

Berdasarkan Tabel 3 dapat diinterpretasikan sebagai berikut: mengganggu lebih penting 3.21 kali daripada mengancam, mengganggu, dan mengancam 1.48 kali dari kerusakan, mengganggu lebih penting 1.69 kali daripada kerugian, mengancam lebih penting 1.38 kali daripada kerusakan, kerugian lebih penting 0.89 kali dari mengancam, kerusakan lebih penting dan 1.93 kali dari kerugian. Dari tabel di atas dapat diketahui jika nilai dari matriks perbandingan di atas, memiliki nilai inconsistency sebesar 0.06747. Nilai rasio ini diartikan bahwa hasil pembobotan pada kriteria bencana dapat diterima karena memiliki $\mathrm{Cl} \leq 0,1$ atau jawaban responden konsisten.

Tabel 4. Nilai bobot dan tingkat prioritas yang dihasilkan.

\begin{tabular}{|c|c|c|}
\hline & Normalized & Idealized \\
\hline Kerugian & 0.169 & 0.420 \\
\hline Kerusakan & 0.233 & 0.581 \\
\hline Mengancam & 0.199 & 0.499 \\
\hline Mengganggu & 0.399 & 1 \\
\hline
\end{tabular}

Berdasarkan hasil perhitungan pada Tabel 4 terdapat nilai normalized dan idealized. Nilai normalized merupakan nilai bobot tiap kriteria, sedangkan nilai idealized merupakan hasil perbandingan bobot kriteria dengan bobot terbesar kriteria. Maka hasil yang didapatkan yaitu kriteria mengganggu merupakan kriteria prioritas dengan nilai bobot paling tinggi yaitu nilai normalized 0.399. Berdasarkan nilai idealized didapatkan hasil yaitu nilai kerusakan yaitu 0.581 atau $58 \%$ dari nilai mengganggu, mengancam $49 \%$ dari nilai mengganggu, kerugian $42 \%$ dari nilai mengganggu. 
Tabel 5. Kesimpulan hasil perhitungan bobot masing-masing kriteria.

\begin{tabular}{cclc}
\hline \multicolumn{1}{c}{ Kriteria } & Bobot & \multicolumn{1}{c}{ Alternatif } & Bobot \\
\hline Mengganggu & 0.399 & Banjir & 0.3376 \\
& & Angin puting beliung & 0.1931 \\
& & Tanah longsor & 0.1694 \\
& & Abrasi & 0.1588 \\
Kerusakan & & Kebakaran Hutan & 0.1409 \\
& \multirow{2}{*}{0.233} & Banjir & 0.2694 \\
& & Angin puting beliung & 0.2394 \\
& & Kebakaran Hutan & 0.2120 \\
Mengancam & Abrasi & 0.1602 \\
& \multirow{2}{*}{0.199} & Tanah longsor & 0.1185 \\
& & Banjir & 0.2984 \\
& Abrasi & 0.2073 \\
& & Tanah longsor & 0.1004 \\
Kerugian & Kebakaran hutan & 0.2349 \\
& & Angin puting beliung & 0.1588 \\
& \multirow{2}{*}{0.169} & Banjir & 0.4480 \\
& & Tanah longsor & 0.1905 \\
& Kebakaran hutan & 0.1402 \\
& Angin puting beliung & 0.1374 \\
& & Abrasi & 0.08360 \\
\hline
\end{tabular}

Berdasarkan Tabel 5 dapat diketahui bobot dari masing-masing alternatif dengan kriteria. Dari hasil tersebut dapat disimpulkan bencana banjir merupakan bencana prioritas pada tiap kriteria dengan memiliki bobot paling tinggi di antara alternatif bencana lainnya. Dari kriteria mengganggu bencana banjir memiliki bobot 0.3376 , sedangkan bobot bencana banjir kriteria kerusakan yaitu 0.2694 , untuk bobot bencana banjir kriteria mengancam 0.2984 , dan bobot bencaa banjir kriteria kerugian adalah 0.4480 .

Untuk itu bencana banjir merupakan bencana prioritas yang mempengaruhi ketahanan Kota Balikpapan dapat dilihat berdasarkan kriteria mengganggu, merusak, mengancam, dan menyebabkan kerugian. Hal tersebut merupakan hasil perhitungan bobot berdasarkan (Analytical Hierarchy Process) dari penggunaan aplikasi super decision. Bencana banjir memang merupakan bencana yang memiliki kerugian paling besar dan bencana yang paling menyebabkan kerusakan baik merusak rumah warga maupun fasilitas, dan menyebabkan korban jiwa paling banyak.

\subsection{Analisa kriteria ketahanan kota berdasarkan bencana prioritas Kota Balikpapan} Berikut merupakan variabel yang digunakan dalam penelitian ini:

a. Aspek Kesehatan dengan indikator layanan kesehatan

b. Aspek Ekonomi dengan indikator tingkat pendapatan daerah 
c. Aspek Infrastruktur dengan indikator air, energi, konektivitas jalan, transportasi, perlindungan struktur, infrastruktur hijau, desain dan bangunan, teknologi dan informasi, ketersediaan asset alam dan buatan.

d. Aspek strategi dengan indikator perencanaan

Variabel di atas merupakan input dari tahapan analisis untuk menentukan kriteria ketahanan Kota Balikpapan dengan menggunakan teknik analisis delphi. Tujuan dari analisis ini adalah untuk mereduksi variabel kriteria ketahanan Kota Balikpapan berdasarkan pendapat para stakeholders, dengan menarik kesimpulan pendapat stakeholders berdasarkan kesetujuan dan ketidaksetujuan terhadap kriteria yang telah diidentifikasi. Stakeholders didapat dari purposive sampling dan didapatkan Bappeda Kota Balikpapan, BPBD Kota Balikpapan, masyarakat Kota Balikpapan yang terdampak bencana banjir, dan akademisi yang ahli dalam bidang kebencanaan. Sehingga dapat ditarik sebuah kesepakatan atau consensus tentang kriteria ketahanan Kota Balikpapan. Apabila terdapat perbedaan pendapat maka akan dilakukan tahapan wawancara kembali (iterasi) hingga tercapainya kesepakatan atau consensus terkait kriteria ketahanan Kota Balikpapan. Iterasi dalam tahapan ini dilakukan sebanyak tiga kali.

Secara keseluruhan analisis delphi dilakukan dengan 3 kali putaran dimana hal tersebut dilakukan untuk mencapai kesepakatan atau consensus. Dari hasil iterasi tersebut dapat diketahui apabila variabel yang disetujui adalah aspek kesehatan dengan indikator layanan kesehatan, aspek infrastruktur dengan indikator air, energi, konektivitas jalan, transportasi, perlindungan struktur, infrastruktur hijau, desain dan bangunan, teknologi dan informasi, aspek strategi dengan indikator perencanaan. Sedangkan terdapat indikator yang tidak disetujui yaitu aspek ekonomi pendapatan daerah, dan aspek infrastruktur yaitu ketersediaan asset alam dan buatan. Kedua indikator tersebut menurut para stakeholders tidak ada hubungannya dengan kriteria ketahanan kota. Selain kriteria dan indikator tersebut terdapat penambahan indikator lainnya yang juga telah disetujui oleh stakeholders yaitu aspek infrastruktur yaitu infrastruktur persampahan dan aspek kapasitas masyarakat dalam kesiapsiagaan menghadapi bencana. Tabel 6 merupakan kriteria ketahanan Kota Balikpapan yang telah disepakati oleh stakeholders.

Tabel 6. Kesimpulan kriteria ketahanan Kota Balikpapan dalam menghadapi bencana banjir.

\begin{tabular}{llll}
\hline Aspek & Indikator & Aspek & Indikator \\
\hline Kesehatan & Layanan Kesehatan & Strategi & Perencanaan \\
Infrastruktur & Air & Budaya Masyarakat & Kapasitas Masyarakat \\
& Energi & & \\
Konektivitas jalan, & & \\
& Transportasi & & \\
& Perlindungan struktur, & & \\
& Infrastruktur hijau & & \\
& Desaindanbangunan, & \\
& Teknologidaninformasi, & & \\
& Persampahan & \\
\hline
\end{tabular}




\section{Kesimpulan}

Strategi resilient city merupakan bentuk upaya dalam menghadapi ancaman sebuah kota, yang tersusun berdasarkan tiga dimensi yaitu mitigasi, adaptasi, dan respons. Dimana untuk merumuskan strategi resilient city tersebut diperlukan langkah-langkah yang tertuang dalam sebuah sasaran. Menganalisa jenis bencana prioritas yang mempengaruhi ketahanan Kota Balikpapan, menganalisa kriteria ketahanan kota (resilient city) berdasarkan jenis bencana di Kota Balikpapan, merumuskan strategi kota berketahanan (resilient city) yang sesuai di Kota Balikpapan. Maka didapatkan hasil kesimpulan sebagai berikut:

a. Pada sasaran penelitian pertama, metode analisis yang digunakan adalah Analytical Hierarchy Process (AHP). Hasil dari analisis tersebut adalah jenis bencana prioritas yang mempengaruhi ketahanan Kota Balikpapan. Dimana hasilnya adalah bencana banjir yang menjadi prioritas dengan nilai bobot tertinggi dibandingkan dengan bencana lainnya seperti tanah longsor, abrasi, angin puting beliung, dan kebakaran hutan. Penilaian bencana banjir tersebut dinilai oleh 5 stakeholders yang telah ditentukan, berdasarkan kriteria yang paling mengganggu, paling mengancam, paling merusak, dan paling merugikan.

b. Pada sasaran kedua, metode analisis yang digunakan adalah analisis delphi. Hasil dari analisis delphi adalah kriteria ketahanan kota (resilient city) berdasarkan jenis bencana prioritas yaitu bencana banjir. Kriteria tersebut berasal dari tinjauan literatur sehingga didapatkan kriteria sebagai berikut aspek kesehatan dengan indikator layanan kesehatan, aspek ekonomi dengan indikator pendapatan daerah, aspek infrastruktur dengan indikator air, energi, konektivitas jalan, transportasi, perlindungan struktur, desain dan bangunan, teknologi informasi, infrastrukturhijau, ketersediaan asset, aspek strategi dengan indikator perencananaan. Kriteria tersebut kemudian ditanyakan kepada 5 stakeholders untuk disetujui atau tidak, kemudian berdasarkan hasil wawancara setelah melakukan 3 kali pengulangan didapatkan kesepakatan bahwa kriteria ketahanan kota terhadap bencana banjir adalah sebagai berikut: kriteria ketahanan aspek kesehatan dengan indikator layanan kesehatan, aspek infrastruktur dengan indikator air, energi, konektivitas jalan, transportasi, perlindungan struktur, desain dan bangunan, teknologi informasi, infrastruktur hijau, persampahan, aspek strategi dengan indikator perencananaan, dan aspek sosial masyarakat dengan indikator kesiapsiagaan masyarakat.

\section{Referensi}

[1] BNPB 2017 IRBI (Indeks Risiko Bencana Indonesia) [Internet] BNPB Diakses dari http://inarisk.bnpb.go.id/irbi

[2] BNPB 2016 Kebijakan dan Strategi Penanggulangan Bencana 2015 - 2019 Diakses dari http://mpbi.info/download/KEBIJAKAN\%20STRATEGIS\%20PB\%202015-2019.pdf

[3] BPBD 2018 Gambaran Umum Bencana Kota Balikpapan (BPBD : Balikpapan)

[4] Intergovernmental Panel on Climate Change (IPCC) 2014 AR4 Climate Change 2007: Impacts, Adaptation And Vulnerability Contribution Of Working Group II to the Fourth Assessment Report Of The Intergovernmental Panel On Climate Change ed Parry ML, Canziani OF, Palutikof JP, van der Linden PJ, Hanson CE (New York: Cambridge University Press) Diakses dari https://www.ipcc.ch/report/ar4/wg2/ 
[5] Setiadi R dan Wulandari F 2016 Memadukan Strategi, Mewujudkan Ketahanan: Sebuah Pembelajaran dari Pengembangan Strategi Ketahanan Kota di Semarang Jurnal Pengembangan Kota 42 pp 95-105 DOI: 10.14710/jpk.4.2.95-105

[6] Pemerintah Provinsi DKI Jakarta dan Sekretariat Jakarta Berketahanan 2019 Strategi Ketahanan Kota Jakarta [Internet] Diakses dari https://issuu.com/jakberketahanan/docs/strategi_ketahanan_kota_jakarta_final_2 _pages

[7] Brooks N 2003 Vulnerability, Risk and Adaptation: A Conceptual Framework Tyndall
Centre
Working
Paper
38
$\mathrm{pp}$
1-19
Diakses
dari https://www.researchgate.net/publication/200032746_Vulnerability_Risk_and_Ada ptation_A_Conceptual_Framework 